\title{
Crosstalk among Bcl-2 family members in B-CLL: seliciclib acts via the Mcl-1/Noxa axis and gradual exhaustion of $\mathrm{Bcl}-2$ protection
}

\author{
DYH Hallaert ${ }^{1,2}$, R Spijker ${ }^{1,2}$, M Jak ${ }^{1}$, IAM Derks ${ }^{2}$, NL Alves ${ }^{2}$, FM Wensveen ${ }^{2}$, JP de Boer $^{3}$, D de Jong ${ }^{3}$, SR Green ${ }^{4}$, MHJ van Oers ${ }^{1}$ and \\ E Eldering ${ }^{*, 2}$
}

Seliciclib (R-roscovitine) is a cyclin-dependent kinase inhibitor in clinical development. It triggers apoptosis by inhibiting de novo transcription of the short-lived Mcl-1 protein, but it is unknown how this leads to Bax/Bak activation that is required for most forms of cell death. Here, we studied the effects of seliciclib in B-cell chronic lymphocytic leukemia (B-CLL), a malignancy with aberrant expression of apoptosis regulators. Although seliciclib-induced Mcl-1 degradation within $4 \mathrm{~h}$, Bax/Bak activation occurred between 16 and $20 \mathrm{~h}$. During this period, no transcriptional changes in apoptosis-related genes occurred. In untreated cells, prosurvival Mcl-1 was engaged by the proapoptotic proteins Noxa and Bim. Upon drug treatment, Bim was quickly released. The contribution of Noxa and Bim as a specific mediator of seliciclib-induced apoptosis was demonstrated via RNAi. Significantly, $16 \mathrm{~h}$ after seliciclib treatment, there was accumulation of Bcl-2, Bim and Bax in the 'mitochondria-rich' insoluble fraction of the cell. This suggests that after Mcl-1 degradation, the remaining apoptosis neutralizing capacity of Bcl-2 is gradually overwhelmed, until Bax forms large multimeric pores in the mitochondria. These data demonstrate in primary leukemic cells hierarchical binding and crosstalk among Bcl-2 members, and suggest that their functional interdependence can be exploited therapeutically.

Cell Death and Differentiation (2007) 14, 1958-1967; doi:10.1038/sj.cdd.4402211; published online 17 August 2007

B-cell chronic lymphocytic leukemia (B-CLL) is a heterogeneous disease, typified by the accumulation of long-lived monoclonal $B$ cells arrested at the $G_{0} / G_{1}$ phase of the cell cycle. ${ }^{1} \mathrm{~B}-\mathrm{CLL}$ is considered a malignancy involving deregulated apoptosis. High levels of prosurvival $\mathrm{Bcl}-2$ and $\mathrm{Mcl}-1$ proteins can be detected in B-CLL, which are associated with aggressive disease and refractoriness to chemotherapy. ${ }^{2,3}$ Contrasting with these clinical observations, CLL cells succumb easily to 'spontaneous' apoptosis during in vitro culture. So it remains unclear whether overexpression of these antiapoptosis proteins is strictly required to block imminent apoptosis, or affords protection during stress or drug treatment. This aspect is particularly relevant in light of the concept of 'oncogene addiction', which holds that each cancer type may strictly depend on just a few particular oncogenes, like Bcl-2. ${ }^{4}$

A proapoptotic subgroup within the Bcl-2 family consists of the so-called BH3-only proteins and includes Bid, Bim, Noxa, Puma, Bad, Bmf, Bik and Hrk. By forming heterodimeric complexes at the mitochondria, the interplay between $\mathrm{BH} 3-$ only proteins and prosurvival Bcl-2-like counterparts determines the activation of proapoptotic Bax-like members and subsequent cell death. ${ }^{5}$ Paradoxically, Noxa and Bmf are overexpressed in circulating B-CLL cells ${ }^{6}$ although the functional significance of these observations remains unclear. Puma, a bonafide p53 target gene, ${ }^{7,8}$ is rapidly induced in B-CLL cells obtained from the majority of patients upon treatment with therapeutic drugs such as fludarabine and chlorambucil. ${ }^{6}$ Still, it has been difficult to demonstrate an improvement in overall survival upon treatment with these chemotherapeutic drugs and disease relapse is inevitable in virtually all patients. ${ }^{1}$ Up to $30 \%$ of B-CLL tumors have a defect in the p53 pathway, which is often associated with resistance to therapy. Therefore, there is an urgent need for novel drugs that work independently of p53.

Recently, the cyclin-dependent kinase (CDK) inhibitor seliciclib (CYC202, R-roscovitine), has emerged as a potential drug for treatment of B-cell malignancies including B-CLL. ${ }^{9}$ Another CDK inhibitor, flavopiridol has recently been tested in CLL with encouraging results. ${ }^{10}$ Seliciclib induces apoptosis, most likely by inhibiting RNA polymerase II-dependent transcription and thereby resulting in loss of the short-lived prosurvival $\mathrm{Mcl}-1$ protein. ${ }^{11}$ Yet, it remains unresolved how the decrease in $\mathrm{Mcl}-1$ levels is coupled to apoptosis induction.

\footnotetext{
${ }^{1}$ Department of Hematology, Academic Medical Centre (AMC), Amsterdam, The Netherlands; ${ }^{2}$ Department of Experimental Immunology, Academic Medical Centre (AMC), Amsterdam, The Netherlands; ${ }^{3}$ Department of Pathology, The Netherlands Cancer Institute/Antoni van Leeuwenhoek Hospital, Amsterdam, The Netherlands and ${ }^{4}$ Cyclacel Ltd., Dundee Technopole, James Lindsay Place, Dundee, DD1 5JJ, UK

${ }^{*}$ Corresponding author: E Eldering, Department of Experimental Immunology, Academic Medical Center (AMC), Meibergdreef 9, Room L1-106, 1105 AZ Amsterdam, The Netherlands. Tel: + 31 205666076; Fax: 31 205669756; E-mail: e.eldering@amc.uva.nl

Keywords: R-roscovitine; Bcl-2; bax; mitochondria

Abbreviations: B-CLL, B-cell chronic lymphocytic leukemia; C9DN, Caspase-9-DN; Cab, Control Ab; CCCP, m-chlorophenylhydrazone; CDK, Cyclin-dependent kinase; CHAPS, 3[(3-cholamidopropyl)dimethylammonio]-propane-sulfonic acid; DCF, Dutch Cancer Foundation; DMSO, Dimethyl sulfoxide; F, Female; FCS, Fetal calf serum; Fluda, Fludarabine; IMDM, Iscove's Modified Dulbecco's Medium; IP, co-immunoprecipitation; M, Male; M, Muted; mAb, Monoclonal antibody; PBMC, Peripheral blood mononuclear cells; PI, Propidium iodide; SDS-PAGE, Sodium dodecyl sulfate-polyacrylamide gel electrophoresis; Stauro, Staurosporine; UM, Unmutated Received 05.2.07; revised 05.6.07; accepted 26.6.07; Edited by P Bouillet; published online 17.8.07
} 
Despite the notion that Bax and Bak are indispensable for apoptosis, ${ }^{12}$ the molecular cascade that mediates their activation is presently a matter of debate. New developments have shed light on the interaction between members of the Bcl-2 family. Specifically, the pivotal prosurvival Mcl-1 interacts, among others, with Noxa, Bim, Puma and Bak in model cell lines. ${ }^{13,14}$ These findings may be relevant in connection with our observation of elevated expression of Noxa in B-CLL, ${ }^{6}$ and in light of the above-mentioned concept of 'oncogene addiction.'

In the present study, we investigated the molecular mechanism underlying apoptosis elicited by seliciclib in B-CLL, with emphasis on protein interactions between Bcl-2 family members. We show for the first time that $\mathrm{Mcl}-1$ is associated with Noxa in primary leukemic cells and that Noxa is required to trigger the mitochondrial apoptosis pathway upon seliciclib treatment. Furthermore, despite rapid proteasome-dependent degradation of Mcl-1 (within $4 \mathrm{~h}$ ), Bax/Bak activation and apoptosis are substantially delayed (16-20 h). During this time, Bim and Bax become associated with $\mathrm{Bcl}-2$ and these proteins eventually translocate to a mitochondriarich insoluble fraction. Our data suggest that in the absence of $\mathrm{Mcl}-1$, the remaining apoptosis neutralizing capacity of $\mathrm{Bcl}-2$ is gradually overwhelmed, resulting in Bax/Bak multimerization and pore formation in the mitochondria.

\section{Results}

Seliciclib induces apoptosis and rapid proteasomedependent degradation of $\mathrm{Mcl}-1$. The effect of seliciclib on cell viability was investigated in $20 \mathrm{~B}-\mathrm{CLL}$ samples. B-CLL cells were $>90 \%$ pure as determined by flow cytometry. Consistent with previous reports, ${ }^{15}$ in vitro culture of B-CLL cells was accompanied by a moderate spontaneous increase in apoptosis. Increasing doses $(10,25$ and $50 \mu \mathrm{M})$ of seliciclib resulted in dose-dependent increase of apoptosis (Figure 1a). In comparison, cells treated with a high dose of fludarabine $(100 \mu \mathrm{M})$ showed a lower level of apoptosis at $24 \mathrm{~h}$ of treatment (Figure 1a), but this increased over time (data not shown). IgV $\mathrm{H}_{\mathrm{H}}$ mutated and unmutated B-CLL patients $(n=8$ versus $n=12)$ showed no difference in apoptosis induction by seliciclib (data not shown).

Seliciclib was reported to result in rapid proteasomal breakdown of $\mathrm{Mcl}-1$ protein. ${ }^{11} \mathrm{Mcl}-1$ is also described as a substrate for caspase-mediated degradation. ${ }^{16}$ We tested which of these pathways predominates in B-CLL. Seliciclib was applied in combination with zVAD-fmk and the proteasome inhibitors MG132 and bortezomib. As shown in Figure $1 \mathrm{~b}$, the degradation of Mcl-1 in B-CLL cells was at best partially affected by zVAD-fmk (lane 2 versus lane 3 ). In contrast, the proteasome inhibitors MG132 and bortezomib almost fully prevented Mcl-1 degradation (lane 2 versus lanes 4 and 5). Thus, in B-CLL cells $\mathrm{Mcl}-1$ is largely degraded already $4 \mathrm{~h}$ after addition of seliciclib, predominantly via the proteasome.

In B-CLL, Mcl-1 associates with Noxa and Bim but not with Bak. Prior studies in model cell lines indicate that Mcl-1 selectively interacts with Bim, Bak, Puma and Noxa, whereas

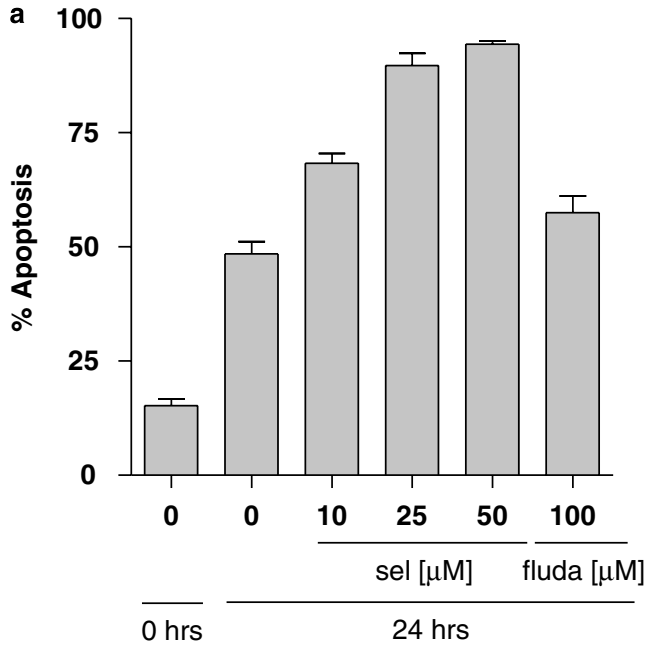

b

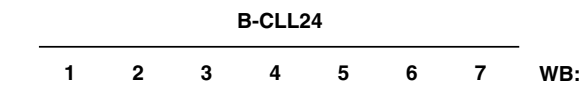

$37 \mathrm{kD}$

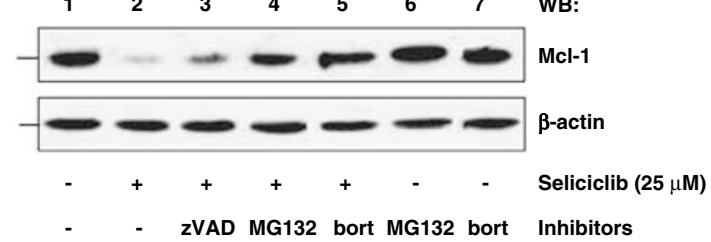

Figure 1 Apoptosis and Mcl-1 degradation in $\mathrm{B}-\mathrm{CLL}$ upon seliciclib treatment. (a) B-CLL cells $(n=20)$ were treated with seliciclib $(0,10,25$ or $50 \mu \mathrm{M})$ or fludarabine $(100 \mu \mathrm{M})$. Apoptosis was determined via Annexin- $\mathrm{V}^{\mathrm{APC}} / \mathrm{PI}$ staining at 0 and $24 \mathrm{~h}$. (b) B-CLL cells were untreated (lanes 1,6 and 7) or treated with $25 \mu \mathrm{M}$ seliciclib (lanes 2-5) for $4 \mathrm{~h}$. Where indicated, cells were pretreated for $1 \mathrm{~h}$ with $100 \mu \mathrm{M}$ zVAD-fmk, $10 \mu \mathrm{M}$ MG132 or $2 \mu \mathrm{M}$ bortezomib. Samples containing $30 \mu \mathrm{g}$ of protein were analyzed by western blotting for the presence of Mcl-1 (top panel) and $\beta$-actin (bottom panel) as loading control. Experiments were repeated twice times with similar results

Noxa has a strong preference for $\mathrm{Mcl}-1$ and possibly Bfl-1. ${ }^{13,14,17}$. In primary B-CLL cells, the majority of Noxa protein was associated with Mcl-1 (Figure 2, compare IP with cleared lysate lanes). As also reported for normal tonsil B cells, ${ }^{18}$ Bim was clearly but not exclusively associated with $\mathrm{Mcl}-1$. Cells were then analyzed after $2 \mathrm{~h}$ of seliciclib treatment, that is, before extensive degradation of Mcl-1 and zVAD-fmk or MG132 were added to block caspases or the proteasome. Rapid dissociation of Bim from Mcl-1 could be observed, while Noxa was still largely bound (Figure 2, left panels).

Previous studies in HeLa cells indicated that Mcl-1 directly sequesters Noxa, Bim and Bak, and upon UV treatment, Bak is displaced by Noxa. ${ }^{19}$ In B-CLL cells, Mcl-1 was associated with Noxa and Bim, but we consistently could not detect association of $\mathrm{Mcl}-1$ with Bak, irrespective of seliciclib treatment, although Bak was present in CLL lysates (Figure 2, right panel). As expected, proteasome inhibition by MG132 resulted in increased $\mathrm{Mcl}-1$ protein, but also increased Noxa levels (Figure 2, right panels). Bax protein levels were unaffected by either seliciclib or MG132 treatment. In summary, in primary B-CLL cells undergoing seliciclib treatment Noxa remained bound to $\mathrm{Mcl}-1$ while $\mathrm{Bim}$ dissociated. 
Noxa-deficient cells exhibit resistance to seliciclibinduced apoptosis. To test whether the association between Noxa and $\mathrm{Mcl}-1$ was reflected at a functional level, the endogenous levels of Noxa and Mcl-1 were manipulated in model systems via RNAi and overexpression. A significant reduction of Noxa in Ramos FSA cells was achieved with two different siRNA sequences (N7 and N8; Figure 3Aa). Functionally, Noxa RNAi conferred a significant resistance to apoptosis induced by seliciclib compared to the mock-transduced cells (Figure 3B), which correlated with the knockdown in Noxa protein. These data were confirmed in the Mec-1 cell line (Figure $3 \mathrm{C}$ ), originally derived from a B-CLL patient, and the Jurkat $T$ cell line ${ }^{20}$ (Figure 3D). In contrast, upon several other death stimuli like fludarabine, staurosporine, CD95 and BCR stimulation, no significant effect of reduced Noxa levels was observed (Figure 3B). Conversely, increased Mcl-1 levels (Figure 3Ab) conferred resistance to seliciclib, but also to several other apoptotic stimuli (Figure 3E). In agreement with the Mcl-1 association studies in B-CLL presented in Figure 2, knockdown of Bim also resulted in increased resistance against seliciclib. As might be expected from its broader interaction range compared to Noxa, Bim knockdown conferred resistance against diverse apoptotic stimuli, among which was taxol, in agreement with earlier studies. $^{21}$ In conclusion, these data indicate that Noxa functions specifically in case of $\mathrm{Mcl}-1$ degradation, such as after seliciclib treatment.

Delay in Bax/Bak activation upon seliciclib treatment. Most forms of apoptosis ultimately require activation of Bax and/or Bak, which can be monitored with conformation-specific antibodies. ${ }^{22}$ Surprisingly, we observed that at $4 \mathrm{~h}$ after seliciclib treatment, when $\mathrm{Mcl}-1$ degradation was almost complete as shown above, activation of Bax/Bak was still minimal (see Figure 4, upper panel). At $12 \mathrm{~h}$, Bax/Bak activation was still modest (middle panel). Only after $20 \mathrm{~h}$ substantial conformational changes of

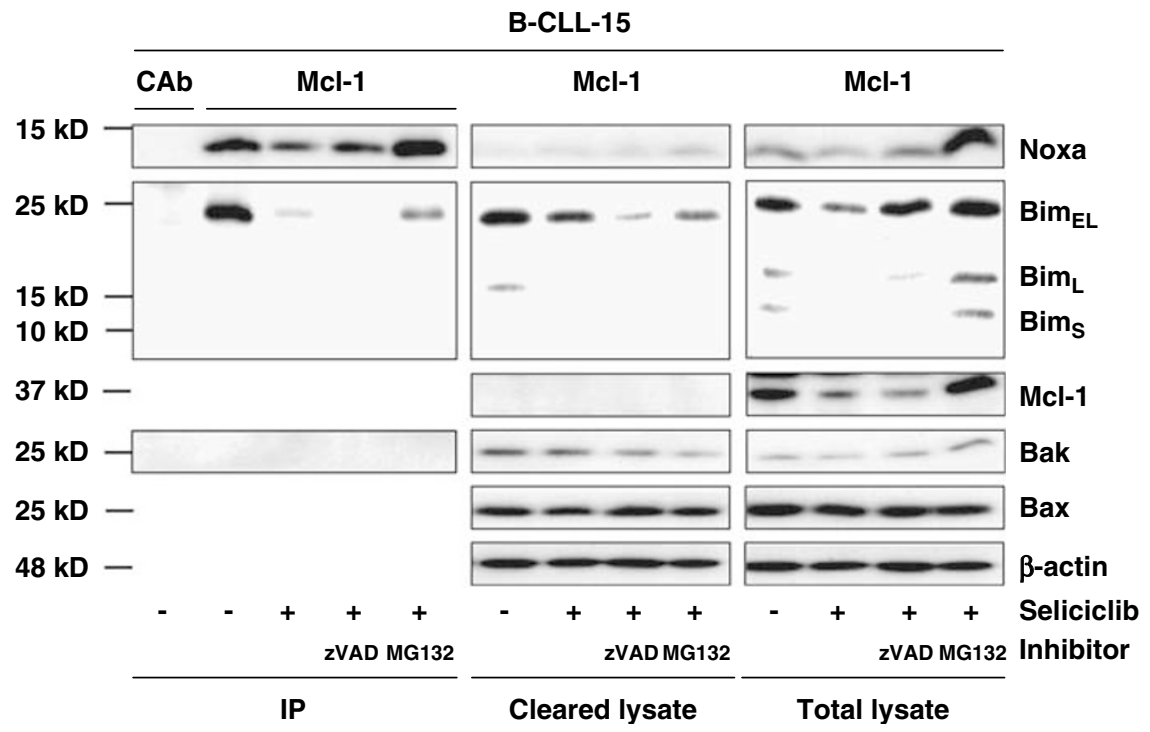

Figure 2 In seliciclib-treated B-CLL cells, Mcl-1 engages Noxa and Bim but not Bak. B-CLL cells were treated with $25 \mu \mathrm{M}$ seliciclib for $2 \mathrm{~h}$. The pan-caspase inhibitors zVAD-fmk $(100 \mu \mathrm{M})$ and proteasome inhibitor MG132 $(10 \mu \mathrm{M})$ were added as indicated. Cell lysates were subjected to IP assays using control Ab (CAb) or anti-Mcl-1 antibody. Bound (IP) and unbound fractions (cleared lysate $=5 \%$ supernatant of lysate after IP) and total cell fractions ( $5 \%$ of total lysate) were analyzed by Western blotting to evaluate protein associations with Mcl-1. The blotting membrane was re-hybridized with anti-Bim, anti-Bak, anti-Bax and anti- $\beta$-actin antibodies as indicated. In the case of $\mathrm{Bim}$, the data is derived from a separate experiment. Experiments were repeated three times with similar results

Figure 3 Noxa RNAi selectively affords resistance to seliciclib, compared to Bim RNAi and Mcl-1 overexpression. Noxa knockdown was obtained using two different Noxa RNAi constructs (N7 and N8) in Ramos and Mec-1 cells. Ramos FSA was transduced with LZRS-Mcl-1-IRES-GFP vector to obtain overexpression of Mcl-1. Bim knockdown in Jurkat T cells was achieved with a Bim RNAi construct, yielding two independent clones B18 and B22. Transduction with empty vectors (M) served as control. Total cell lysates derived from GFP + cells were separated by SDS-PAGE. (A) Noxa, exogenous MCl-1 and Bim protein levels were monitored by western blotting in Ramos FSA, Mec-1 and Jurkat T cells (J16). Mcl-1 was c-myc tagged, which could be characterized with an anti-c-myc antibody. $\beta$-Actin and a non-specific band $\left({ }^{*}\right)$ served as a loading control. (B) Ramos FSA (M) (black), N7 (gray) and N8 (white) were cultured $24 \mathrm{~h}$ in the absence or presence of $25 \mu \mathrm{M}$ seliciclib, $100 \mu \mathrm{M}$ fludarabine (fluda), $0.25 \mu \mathrm{M}$ staurosporine (stauro), $5 \mu \mathrm{g} / \mathrm{ml} \alpha-C D 95$ or $\alpha-B C R$ antibodies. (C) Mec-1 (M) (black) and N8 (gray) were cultured $24 \mathrm{~h}$ in the absence or presence of $50 \mu \mathrm{M}$ seliciclib, $0.25 \mu \mathrm{M}$ staurosporine (stauro) and $5 \mu \mathrm{g} / \mathrm{ml} \alpha$-CD95. (D) J16 (M) (black), N7 (gray) and N8 (white) were cultured as described above with $25 \mu \mathrm{M}$ seliciclib, $0.25 \mu \mathrm{M}$ staurosporine (stauro) and $5 \mu \mathrm{g} / \mathrm{m}$ $\alpha$-CD95. (E) Ramos FSA (M) (black) and Mcl-1 (gray) were cultured in the absence or presence of $25 \mu \mathrm{M}$ seliciclib, $100 \mu \mathrm{M}$ fludarabine (fluda), $0.25 \mu \mathrm{M}$ staurosporine (stauro), $5 \mu \mathrm{g} / \mathrm{ml} \alpha$-CD95 or $\alpha$-BCR antibodies. (F) J16 (M) (black), J16-B18 (gray) and J16-B22 (white) were cultured $24 \mathrm{~h}$ in the absence or presence of $25 \mu \mathrm{M}$ seliciclib, $5 \mu \mathrm{g} / \mathrm{ml}$ $\alpha$-CD95, $3.1 \mu \mathrm{M}$ etoposide, $25 \mu \mathrm{M} \mathrm{CCCP}$, or $5 \mathrm{nM}$ taxol. Apoptosis was assessed by flow cytometry analysis. Data represent mean \pm S.D. from three or more independent experiments, except in E; the CD95 and BCR triggering was carried out two times and no statistics were performed. $P<0.01$ with Student's $t$-test are indicated by an asterisk $\left(^{*}\right)$. In case of Bim knockdown $(\mathbf{F})$, only those stimuli where both clones yielded $P<0.01$ are marked 

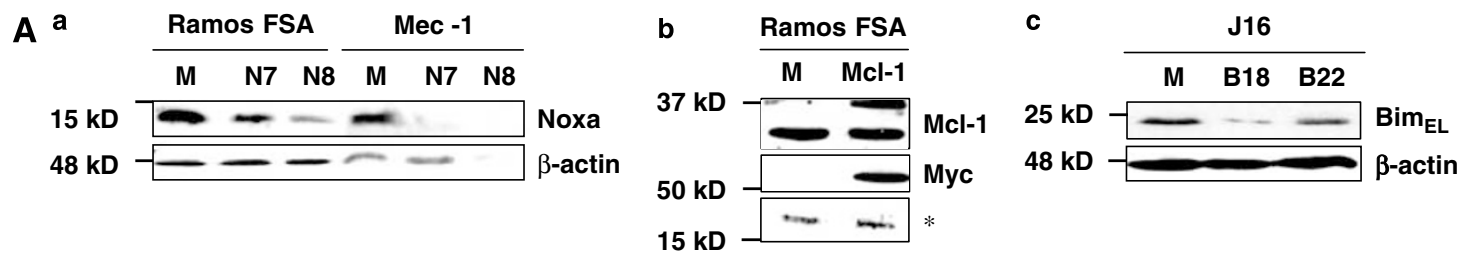

B
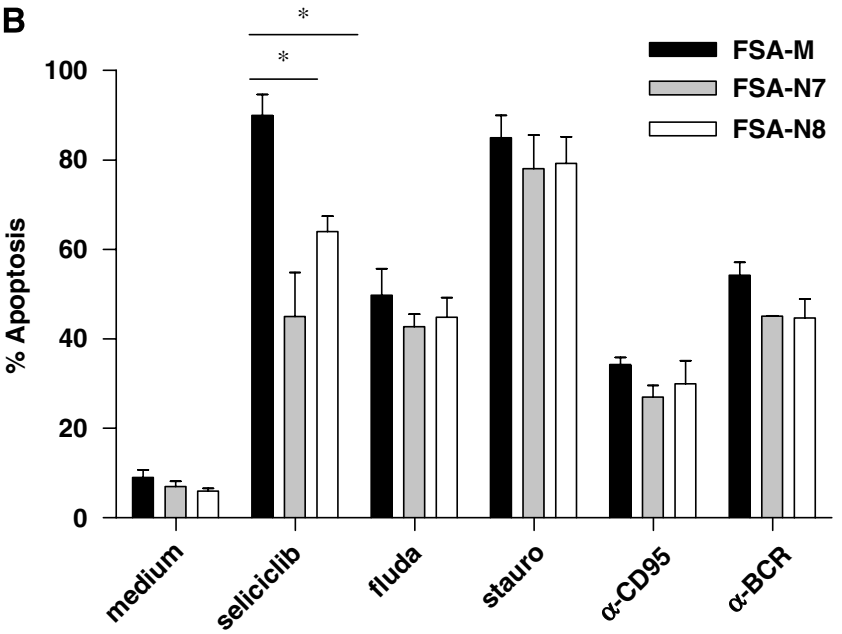

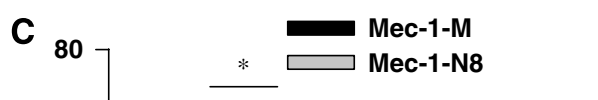

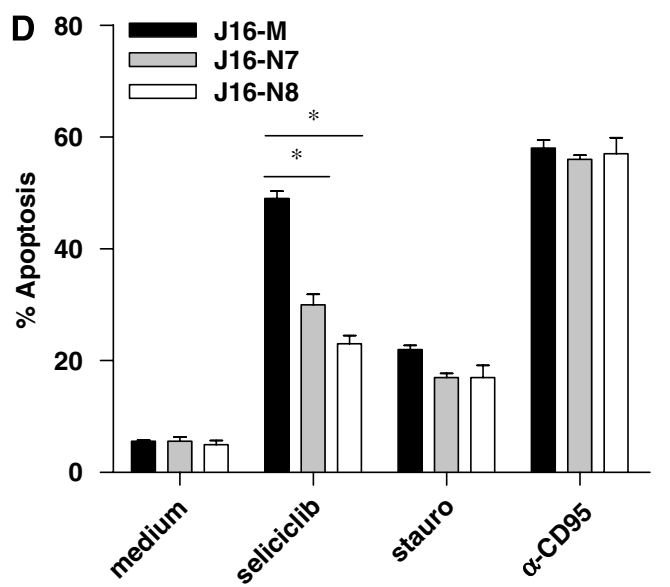
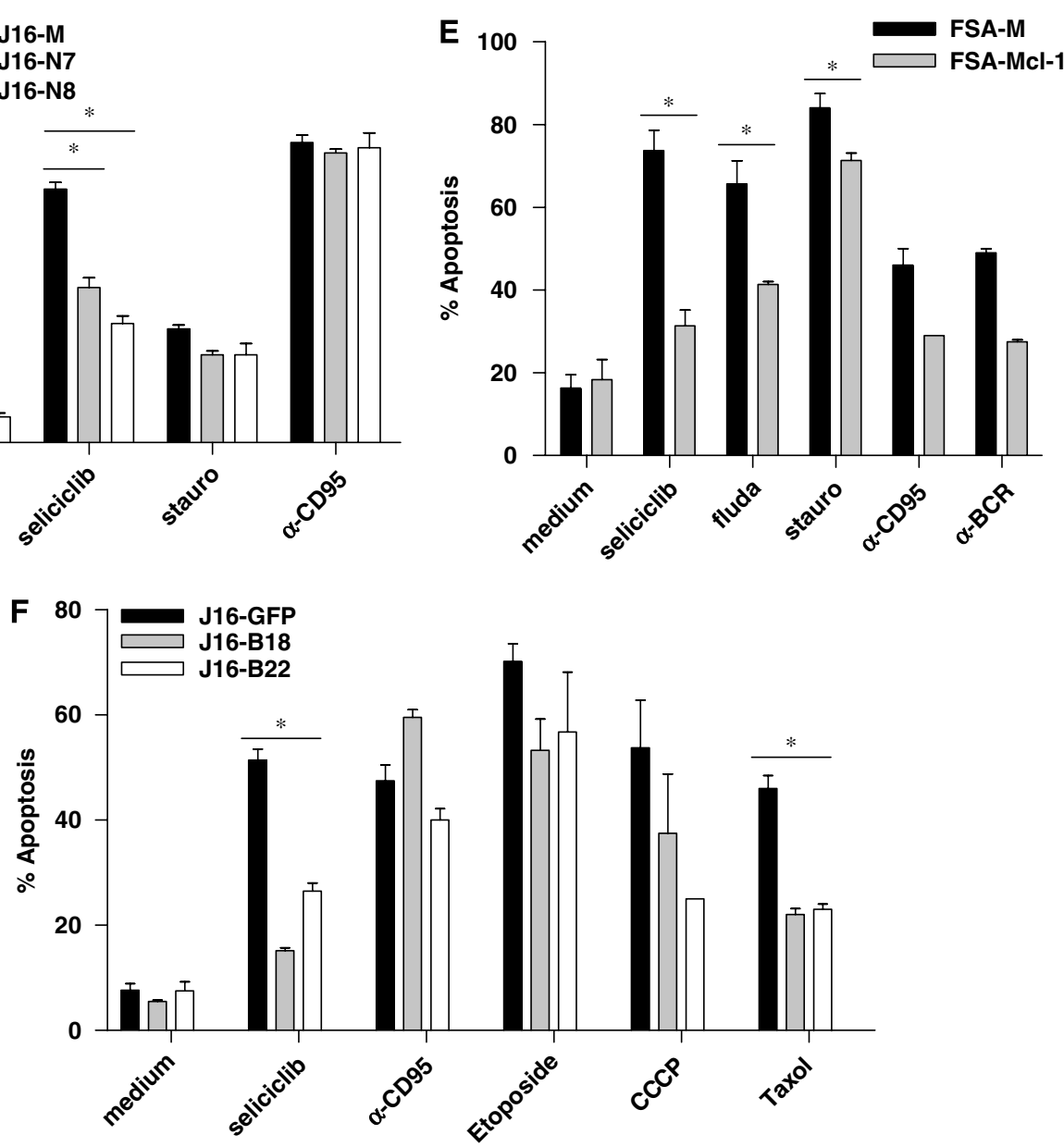


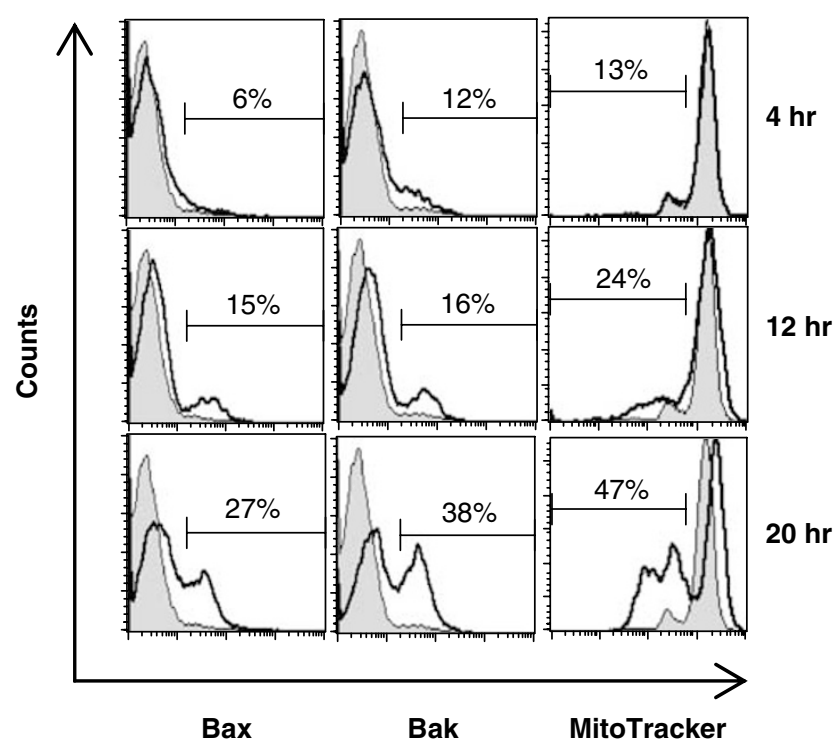

Figure 4 Seliciclib-induced cell death in B-CLL involves loss of the mitochondrial membrane potential and Bax/Bak conformational change. B-CLL cells were incubated in the absence (control, gray peak) or presence of $25 \mu \mathrm{M}$ seliciclib and monitored every $4 \mathrm{~h}$ up to $24 \mathrm{~h}$. Only 4,12 and $20 \mathrm{~h}$ time points are shown. Bax/Bak conformational changes were determined by intracellular flow cytometry using anti-Bax and anti-Bak monoclonal antibodies (solid black lines). For analysis of the mitochondrial membrane potential $\left(\Delta \Psi_{\mathrm{m}}\right)$, cells were incubated with MitoTracker Orange for $30 \mathrm{~min}$

Bax/Bak occurred. At all time points, the mitochondrial membrane potential as measured via MitoTracker staining mirrored the pattern of Bax/Bak activation, and substantial damage occurred only at $20 \mathrm{~h}$. These data were obtained in various $\mathrm{B}-\mathrm{CLL}$ samples tested $(n=3)$ and demonstrate that there was a substantial delay between $\mathrm{Mcl}-1$ degradation and the actual onset of apoptosis. During this period, there were no significant changes in apoptosis-regulatory genes, such as p53-responsive Puma, as detected by RT-MLPA ${ }^{6}$ (data not shown).

Translocation of Bim, Bax and Bcl-2 to the mitochondria-rich insoluble fraction subsequent to Mcl-1 degradation. To elucidate events occurring between Mcl-1 degradation and the onset of apoptosis, we monitored candidate proteins potentially involved in this process. This was carried out by co-immunoprecipitation (IP) of CHAPSsoluble lysates taken 0,4 and $16 \mathrm{~h}$ after seliciclib treatment. The data shown in Figure 2 suggested early dissociation of Bim from $\mathrm{Mcl}-1$. Since Bim can also bind $\mathrm{Bcl}-2$, which is in general highly expressed in B-CLL, we studied Bim associations over time. Bim was bound to $\mathrm{Bcl}-2$ at $0 \mathrm{~h}$, and this association declined following prolonged seliciclib treatment (Figure 5a, left panel). These findings were confirmed in the reverse experiment by IP of Bcl-2 (data not shown). Significantly, at $16 \mathrm{~h}$ of treatment, Bim, Bcl-2 and Bax were detected in the insoluble fraction of the cell (right panel). Moreover, we could not detect association between Bim and Bax or Bak (the latter is generally expressed at low levels in B-CLL cells) in viable nor in apoptotic cells. In accordance with published findings, ${ }^{13,14}$ we could not detect association between $\mathrm{Bcl}-2$ and Noxa. The transition of Bim, Bax and Bcl-2 to the CHAPS-insoluble cell fraction was confirmed by western blotting of four additional B-CLL samples taken after 0,4 and $16 \mathrm{~h}$ of seliciclib treatment (Figure 5b). Together, these data demonstrate that Bim, $\mathrm{Bcl}-2$ and Bax associations change during drug treatment, and this correlates with transition to an insoluble state. The mitochondrial membrane protein porin/VDAC2 was predominantly expressed in the 'mitochondria-rich' insoluble fraction. Presumably, after release from $\mathrm{Mcl}-1$ and subsequently $\mathrm{Bcl}-2$, Bim is responsible for activation of Bax, although this is not detectable via direct interaction in the soluble cell fraction.

As Bax is translocated to the membrane fraction during seliciclib-induced apoptosis, we assessed its subcellular distribution using confocal microscopy. Figure $5 \mathrm{c}$ shows that Bax is localized throughout the cytoplasm in untreated B-CLL cells. Following $16 \mathrm{~h}$ seliciclib treatment $(+$ pretreatment with zVAD), Bax showed a punctate distribution and colocalization with the mitochondria, suggesting that Bax multimerizes at the mitochondria.

Bcl-2 confers a temporary block to seliciclib-induced apoptosis. To directly determine the role of $\mathrm{Bcl}-2$ in the delayed onset of seliciclib-induced apoptosis, we used a Ramos model cell line overexpressing Bcl-2. ${ }^{23}$ In parental Ramos cells treated with seliciclib, $\mathrm{Mcl}-1$ degradation (Figure 6a; upper panel) occurred within $4 \mathrm{~h}$, similar to $\mathrm{B}$ CLL cells (Figure 1b). The decline in Mcl-1 levels occurred independently of caspase activation, as demonstrated by overexpression of C9DN. In contrast to B-CLL, Mcl-1 degradation was almost simultaneous with apoptosis induction, shown by cleavage of effector caspase 3 (Figure 6a; panel 3), and Annexin-V exposure (Figure 6b). Overexpression of $\mathrm{Bcl}-2$ in Ramos cell lines recapitulated the delayed onset of apoptosis after seliciclib treatment observed in B-CLL cells. Clearly, apoptosis was blocked after $4 \mathrm{~h}$ of treatment, whereas at $24 \mathrm{~h}$ virtually all cells were apoptotic, despite the presence of Bcl-2 (Figure 6b). In comparison, time-course analysis of Ramos cells with Noxa knockdown or Mcl-1 overexpression also showed that the block in seliciclibinduced apoptosis was not absolute. Here, the fraction of apoptotic cells increased more gradually over time up to the last point measured (48 h; Figures $6 \mathrm{c}$ and d). The effect of seliciclib on $\mathrm{Mcl}-1$ produced from a recombinant vector may be less than on the endogenous transcript. However, the recently described phosphorylation of Mcl-1 at Ser64 which enhances its apoptotic activity is apparently also prevented by seliciclib, ${ }^{24}$ therefore a complete block of seliciclibinduced apoptosis of overexpressed Mcl-1 is not expected. Together, our data indicate that manipulation of individual $\mathrm{Bcl}-2$ family members is insufficient to warrant full protection to seliciclib, which suggest they are subject to an intricate functional interplay.

\section{Discussion}

In hematological cells, the primary apoptotic trigger ascribed to the novel CDK inhibitor seliciclib is a rapid decrease in Mcl-1 levels independent of p53 function. ${ }^{9,11}$ This is of clinical 
a

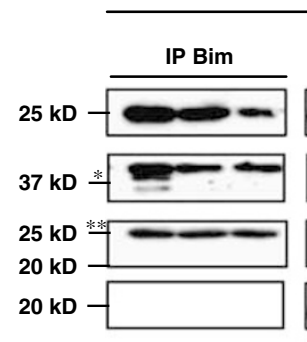

$25 \mathrm{kD}-$

$15 \mathrm{kD}-$

$50 \mathrm{kD}-$

$\begin{array}{rrrr}37 \mathrm{kD}- & & & \\ & 0 & 4 & 16\end{array}$
B-CLL-21
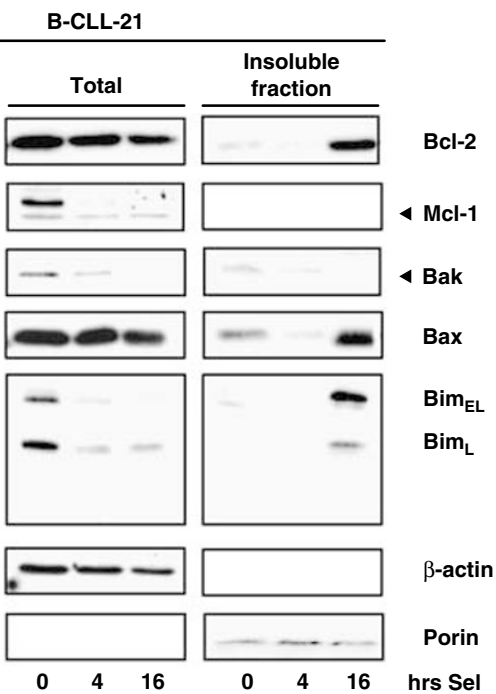

$\beta$-actin b
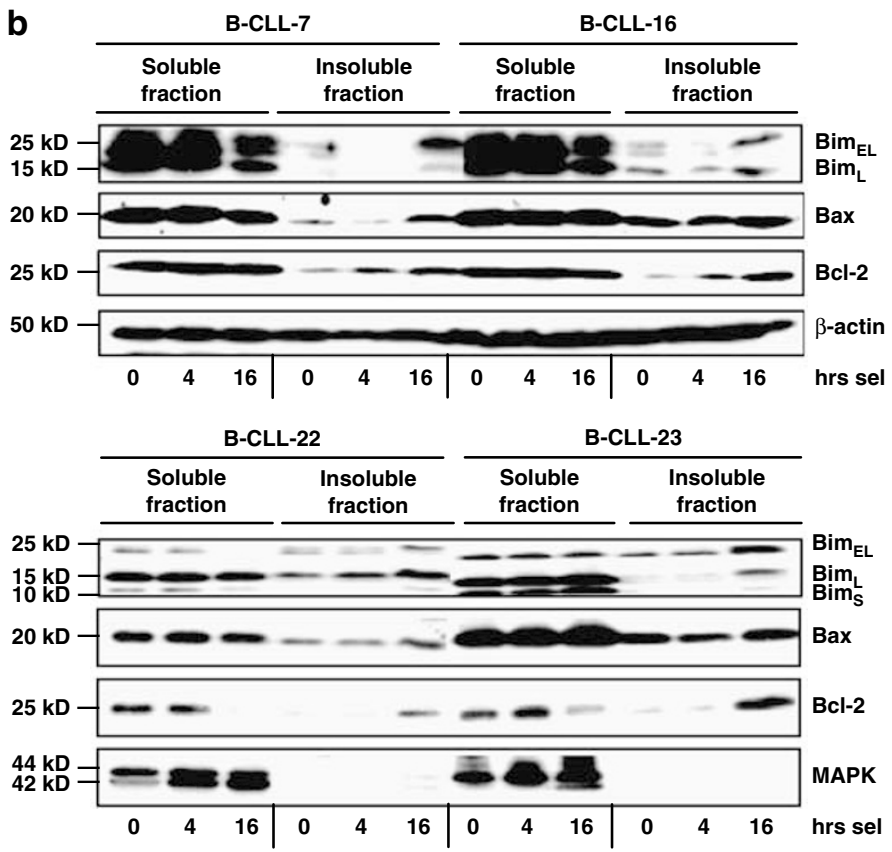

c

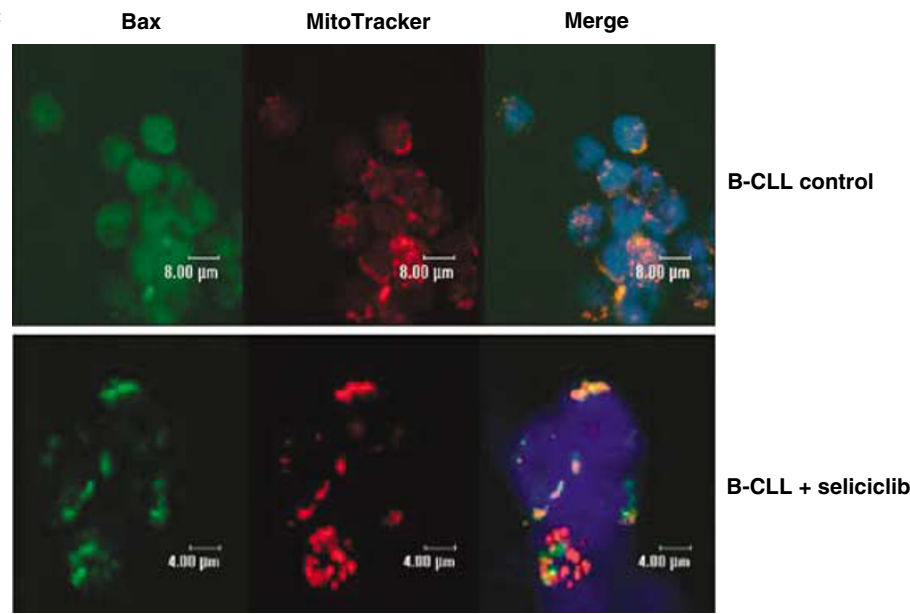

Figure 5 Bim associates with Bcl-2 and Mcl-1 and shifts to the mitochondria-rich insoluble fraction over time in B-CLL cells. B-CLL cells were treated with $25 \mu \mathrm{M}$ seliciclib for 0,4 and $16 \mathrm{~h}$. (a) Cell lysates were subjected to IP assays using a Bim antibody. The bound (IP) fraction (left panel) was analyzed by western blotting to evaluate the association of Bcl-2, Mcl-1, Bak and Bax with Bim over time. Total cell fractions (5\% of total lysate; middle panel) and insoluble fractions (right panel) were monitored by western blotting. The blotting membrane was hybridized with Bcl-2, Mcl-1, Bak, Bax, Bim, $\beta$-actin and Porin antibodies as indicated. (*immunoglobulin heavy chain; **immunoglobulin light chain). (b) CHAPS-soluble and -insoluble fractions from four other B-CLL patients were analyzed by Western blotting to evaluate the localization of Bim, Bax and Bcl-2 over time. (c) Immunocytochemical staining for Bax of B-CLL cells incubated in the absence or presence of $25 \mu \mathrm{M}$ seliciclib for $24 \mathrm{~h}$. MitoTracker Orange was used for localization of the mitochondria

importance in view of the poor prognosis of B-CLL with functional deficiency in the p53 pathway ${ }^{25}$ and the outgrowth of p53-deficient clones during treatment. ${ }^{1}$ Furthermore, there is broad interest in the exact mechanism of action of the various $\mathrm{Bcl}-2$ family members, as it has become clear that their protective function can be targeted also directly by pharmacological compounds. ${ }^{26}$ However, in the absence of a functional link to Bax and/or Bak activation, drug-induced $\mathrm{Mcl}-1$ decrease is in itself not sufficient to explain cell death. Our findings emphasize two new aspects in the chain of events triggered in B-CLL cells upon seliciclib treatment and
Mcl-1 degradation. We found previously that the BH3-only protein Noxa is expressed at high levels in B-CLL, ${ }^{6}$ and here we establish that the molecular effects of seliciclib rely on Noxa. Secondly, subsequent to Mcl-1 degradation, we observed a gradual deterioration of the protection afforded by $\mathrm{Bcl}-2$, which was most probably caused by liberated Bim.

Biochemical studies have shown that distinct BH3-only proteins have differential binding affinities to prosurvival $\mathrm{Bcl}-2$ proteins. ${ }^{13,14,27}$ Reportedly, Noxa has a strong preference for binding to $\mathrm{Mcl}-1$ which we confirm here in primary B-CLL cells (Figure 2). At present, the precise role of Noxa is not entirely 

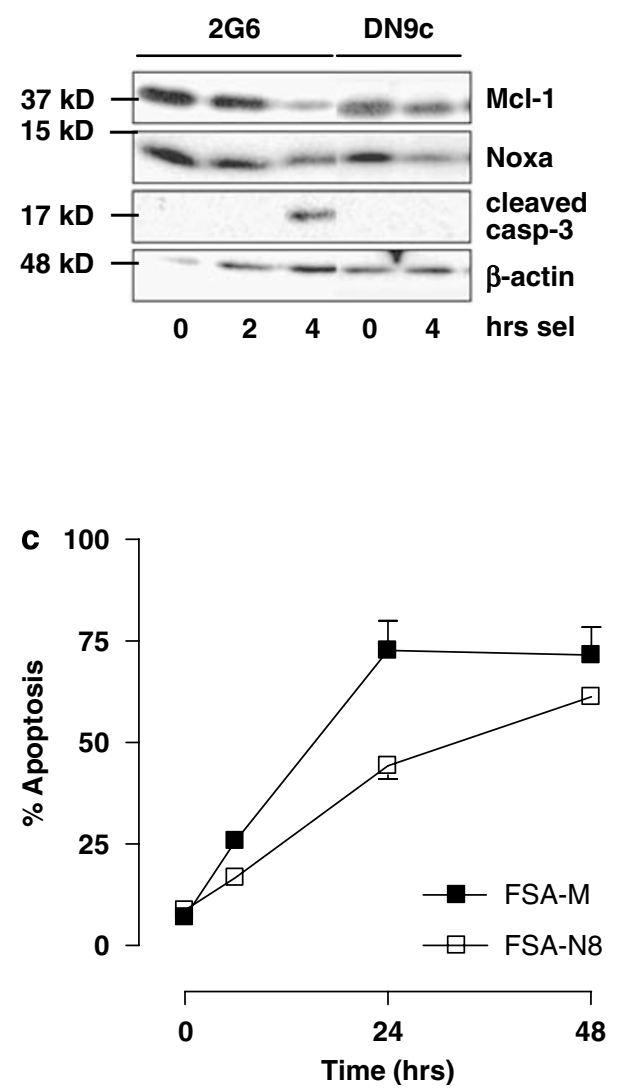
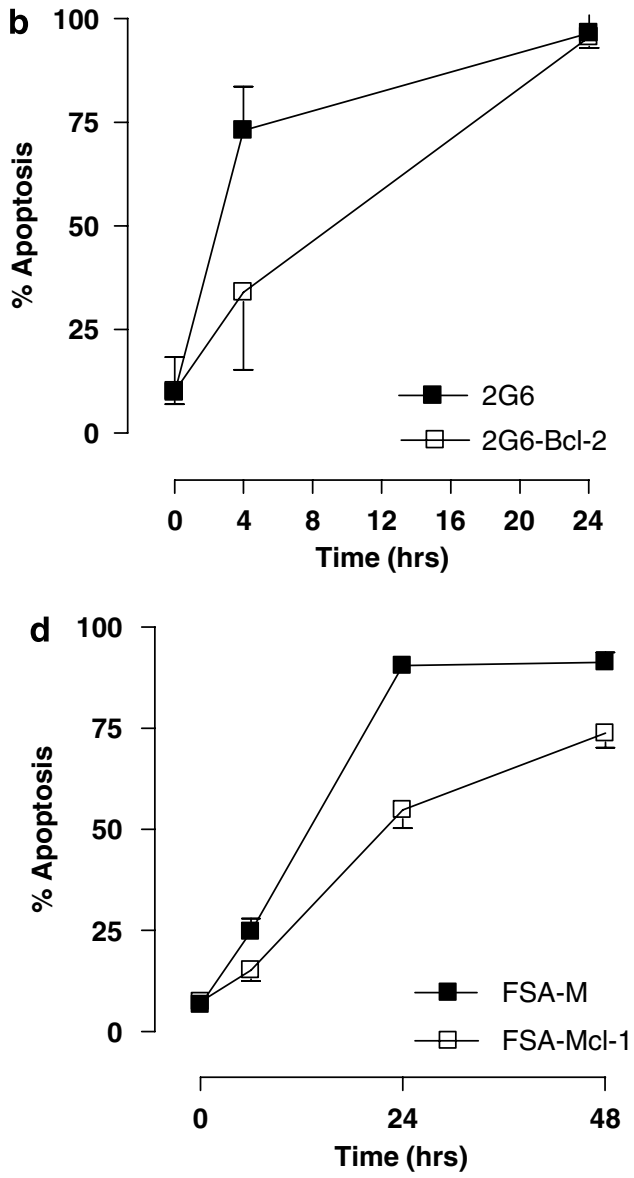

Figure 6 Bcl-2 overexpression in Ramos cell line recapitulates delayed onset of apoptosis. (a) Ramos $2 \mathrm{G} 6$ and Ramos FSA C9DN cells were treated with $25 \mu \mathrm{M}$ seliciclib. At the indicated time points samples were analyzed by western blotting for the presence of Mcl-1 (top panel), Noxa (second panel), activated caspase-3 (third panel) and $\beta$-actin (bottom panel) as loading control. (b) Ramos $2 \mathrm{G} 6$ and Bcl-2 cells $\left(5 \times 10^{5} / \mathrm{ml}\right)$ were left untreated or treated with $50 \mu \mathrm{M}$ seliciclib for 4 and $24 \mathrm{~h}$. (c) Ramos FSA and N8 cells $\left(5 \times 10^{5} / \mathrm{ml}\right)$ were left untreated or treated with $25 \mu \mathrm{M}$ seliciclib for 4,24 and $48 \mathrm{~h}$. (d) Ramos FSA and Mcl-1 cells $\left(5 \times 10^{5} / \mathrm{ml}\right)$ were left untreated or treated with $25 \mu \mathrm{M}$ seliciclib for 4,24 and $48 \mathrm{~h}$. Viability in $\mathbf{b}-\mathbf{d}$ was assessed by means of MitoTracker staining. Data represent mean \pm S.D. from three independent experiments

understood, and our data point to a new and specific role in drug-induced cell death. This was demonstrated by a resistance to seliciclib in Noxa knockdown leukemic cell lines (Figure 3). The difference in Noxa expression did not affect apoptosis by other stimuli (fludarabine, staurosporine, CD95 and $\mathrm{BCR}$ ). Together, these observations imply that the lethal effect of seliciclib in B-CLL cells specifically involves Noxa function. In agreement with their broader interaction range, Mcl-1 overexpression or Bim knockdown had an inhibitory effect on multiple apoptotic stimuli.

Although Noxa levels are 5-10 times higher in B-CLL than in normal $\mathrm{B}$ cells, ${ }^{6}$ this is apparently in itself not a direct trigger for apoptosis, which fits well with the current view of its function as an indirect apoptosis mediator. ${ }^{13,14}$ The available evidence indicates that Noxa acts by displacing proapoptotic $\mathrm{Bcl}-2$ members from $\mathrm{Mcl}-1 .{ }^{19,27}$ We have studied potential involvement of two proapoptotic candidates Bak and Bim in seliciclib-mediated apoptosis in B-CLL. In agreement with studies in HeLa cells, ${ }^{19}$ we found that Noxa can liberate Bak from Mcl-1 in leukemic cell lines (data not shown). However, we consistently could not detect $\mathrm{Mcl}-1$ associated with Bak in primary B-CLL cells. Instead, we observed that the level of
Bim associated with Mcl-1 rapidly declined upon seliciclib treatment, while Noxa remained bound (Figure 2). This is consistent with the differential binding affinities among the BH3-only members reported by others. ${ }^{13,17}$ Once liberated from Mcl-1, Bim is reportedly capable of directly activating Bax and/or Bak. ${ }^{14,27}$ Direct association between Bax or Bak with purported direct $\mathrm{BH} 3-$ only activators such as Bid and Bim in model systems has been described. ${ }^{28,29}$ Yet, direct association of endogenous proteins under physiological conditions is difficult to observe. We were also unable in various co-immunoprecipitation approaches to find Bim complexed with Bax or Bak in early or late apoptotic B-CLL cells. The aspect of direct versus indirect activation of Bax (or Bak) by $\mathrm{BH} 3-$ only members such as Bim is currently the subject of intense research and debate. ${ }^{27,30,31}$ Although it is in fact still unknown what actually causes transition of cytosolic Bax, ${ }^{32}$ its activation is known to result in multimerization and pore formation in mitochondria. ${ }^{33}$ Therefore, we looked for shifts from soluble to insoluble fraction upon apoptosis initiation, and could observe transition of both Bim and Bax to the mitochondria-rich insoluble cell fraction (Figure 5). Our findings in primary B-CLL cells suggest that any direct 
interaction between Bim and Bax is presumably short-lived, and/or induces rapid multimerization and insertion of Bax in the mitochondrial membrane. At this point, the interacting proteins become insoluble and can no longer be detected by standard co-immunoprecipitation approaches. This possible sequence of events upon seliciclib treatment of B-CLL cells is schematically depicted in Figure 7.

The proposed sequence of events from Mcl-1 degradation, Noxa-dependent Bim displacement and liberation, and finally Bax activation is compatible with recent data and interpretations concerning the hierarchical involvement of $\mathrm{BH}$-only members in initiation of the mitochondrial apoptosis pathway. ${ }^{13,27}$ Moreover, a functional linkage between Noxa and Bim was very recently reported in cell lines. ${ }^{34}$ During the period between $\mathrm{Mcl}-1$ degradation and eventual Bax/Bak activation in B-CLL cells, there were no significant changes in gene transcription of $\mathrm{Bcl}-2$ family members (data not shown). The available data suggest that after $\mathrm{Mcl}-1$ degradation, $\mathrm{Bcl}-2$ is temporarily capable of withstanding the proapoptotic action of Bim and Bax, but is progressively overwhelmed. In support of this, overexpression of $\mathrm{Bcl}-2$ in a model system could indeed delay but not prevent apoptosis induced by seliciclib treatment (Figure 6). The gradual undermining of $\mathrm{Bcl}-2$ function could either be a direct effect of seliciclib by an as-yet unknown pathway, or indirectly result from shifts in the distribution of and interactions between $\mathrm{Bcl}-2$ family members.

The findings reported here agree with and complement recent findings concerning the mechanism of action of the BH3-mimetic ABT-737. ${ }^{35,36}$ This compound can counteract the protective function of $\mathrm{Bcl}-2, \mathrm{Bcl}-\mathrm{XL}$ and $\mathrm{Bcl}-\mathrm{w}$ and has potential as a cancer therapeutic. ${ }^{26}$ Cells overexpressing $\mathrm{Mcl}-1$ are however resistant to $\mathrm{ABT}-737$, and strategies to target Mcl-1 levels enhance its efficacy. ${ }^{35,36}$ On the basis of our findings with B-CLL cells reported here and elsewhere, ${ }^{37}$ both direct targeting of $\mathrm{Mcl}-1$ by drugs such as seliciclib and indirect targeting by means of bortezomib to increase Noxa levels, may be a promising combination with ABT-737 or similar compounds. Indeed, it has been shown very recently that seliciclib treatment dramatically increased ABT-737 lethality in human leukemia cell lines. ${ }^{38}$ Overall, the functional crosstalk between $\mathrm{Bcl}-2$ family members suggest that the 'addiction' of leukemic cells to overexpression of antiapoptosis proteins such as $\mathrm{Bcl}-2$ and $\mathrm{Mcl}-1$ could be specifically targeted and exploited in a therapeutic setting.

\section{Materials and Methods}

B-CLL patients and isolation of leukemic B cells. Peripheral blood samples were obtained from B-CLL patients from the outpatient clinic of the Department of Hematology of the Academic Medical Center, Amsterdam; the

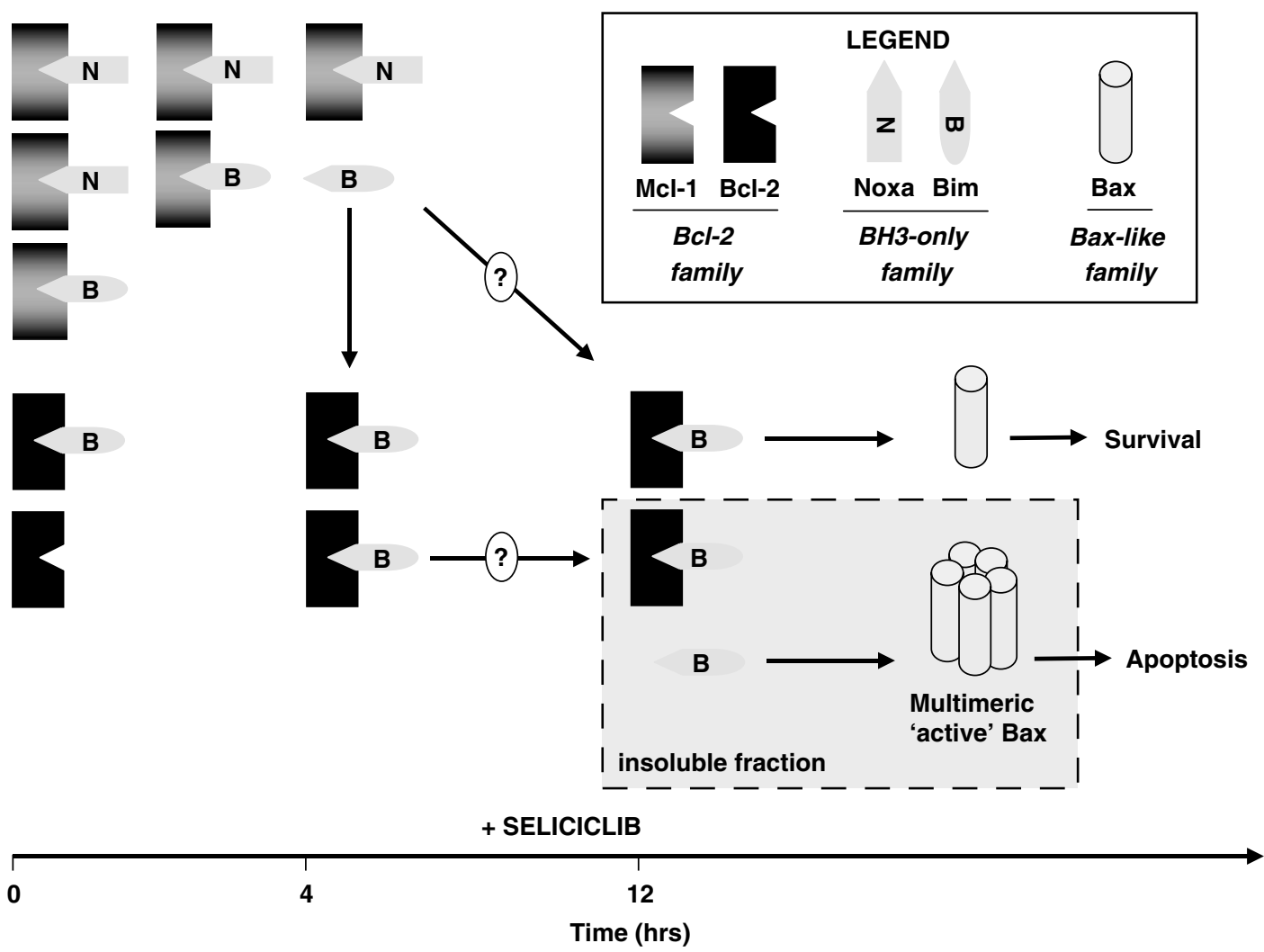

Figure 7 Model for the steps in apoptosis triggered by seliciclib in B-CLL cells. In the initial phase $(<4 \mathrm{~h})$, Mcl-1 is degraded rapidly in a proteasome-dependent manner. As Mcl-1 levels fall, Bim is released while Noxa remains bound. Liberated Bim can be absorbed by Bcl-2 for a while, but gradually there is a transition to a situation where Bcl-2 is no longer capable of binding excess Bim. What is actually causing this transition is unknown. Both disrupting the balance between Bcl-2 family members or unknown signaling events might eventually lead to $\mathrm{Bcl}-2$ dysfunction. From that point on, Bim is able to activate Bax, leading to multimerization and apoptosis. As indicated in the main text, whether Bim activates Bax directly, indirectly or via transient interactions is currently the subject of controversy. Therefore, this scheme only emphasizes that all three direct participants ( $\mathrm{Bcl}-2$, Bim and Bax) shift to an insoluble fraction of the cell, which in the case of multimeric Bax is presumably mitochondrial 
Table 1 Patient's characteristics

Patient no. Sex Age (years) Rai (stage) $\operatorname{lgV}_{\mathrm{H}}$ status Treatment

\begin{tabular}{|c|c|c|c|c|c|}
\hline 1 & $M$ & 63 & 1 & $M$ & ND \\
\hline 2 & $\mathrm{M}$ & 51 & 2 & UM & Yes \\
\hline 3 & $\mathrm{M}$ & 79 & 2 & UM & Yes \\
\hline 4 & $\mathrm{M}$ & 58 & 2 & $M$ & No \\
\hline 5 & $\mathrm{M}$ & 81 & 0 & $M$ & No \\
\hline 6 & $F$ & 56 & 2 & UM & Yes \\
\hline 7 & $\mathrm{M}$ & 65 & 4 & M & No \\
\hline 8 & $\mathrm{M}$ & 64 & ND & UM & Yes \\
\hline 9 & $F$ & 81 & 0 & $\mathrm{M}$ & ND \\
\hline 10 & $M$ & 75 & 0 & $\mathrm{M}$ & No \\
\hline 11 & $\mathrm{M}$ & 72 & 1 & UM & ND \\
\hline 12 & $\mathrm{M}$ & 56 & 2 & UM & Yes \\
\hline 13 & $F$ & 49 & 1 & $\mathrm{M}$ & ND \\
\hline 14 & $\mathrm{M}$ & 71 & 1 & $M$ & ND \\
\hline 15 & $\mathrm{M}$ & 73 & 2 & $\mathrm{M}$ & ND \\
\hline 16 & $M$ & 70 & 2 & UM & ND \\
\hline 17 & $\mathrm{M}$ & 65 & 4 & UM & Yes \\
\hline 18 & $M$ & 60 & 2 & UM & Yes \\
\hline 19 & $\mathrm{M}$ & 50 & 0 & UM & Yes \\
\hline 20 & $\mathrm{M}$ & 56 & 2 & UM & Yes \\
\hline 21 & $M$ & 65 & 1 & $M$ & Yes \\
\hline 22 & $M$ & 65 & ND & $\mathrm{M}$ & ND \\
\hline 23 & $\mathrm{~F}$ & 71 & 0 & $M$ & ND \\
\hline 24 & $\mathrm{~F}$ & 75 & 3 & $\mathrm{M}$ & Yes \\
\hline
\end{tabular}

Of 24 patients the following characteristics were determined at time of inclusion in the study; sex (M, male; F, female); age (in years); Rai stage: 0 (good prognosis), I-II (intermediate prognosis), and III-IV (poor prognosis); $\lg V_{\mathrm{H}}$ mutation status (UM, unmutated $\operatorname{lgV}_{\mathrm{H}}$ genes; $\mathrm{M}=$ mutated $\operatorname{lgV}_{\mathrm{H}}$ genes) and treatment. ND, not determined.

Department of Internal Medicine, Meander Medical Center, Amersfoort and the Department of Internal Medicine, The Netherlands Cancer Institute, Amsterdam. Informed consent was obtained according to the guidelines of the local Ethical Review Board. Clinical characteristics of patients are presented in Table 1. This study was conducted in accordance with the ethical standards in our institutional medical committee on human experimentation, and in agreement with the Helsinki Declaration of 1975, revised in 1983. Peripheral blood mononuclear cells (PBMC), obtained via density-gradient centrifugation were frozen in $15 \%$ fetal calf serum (FCS) containing 10\% dimethyl sulfoxide (DMSO; Sigma Chemical Co., St. Louis, $\mathrm{MO}$, USA) and stored in liquid nitrogen. Expression of CD5, CD19 and CD23 (all Becton Dickinson (BD) Biosciences, San Jose, CA, USA) on leukemic cells was assessed by flow cytometry (FACScalibur, BD Biosciences) and CellQuest Software (BD Biosciences). ${ }^{6}$

Cell lines, retroviral constructs and transduction. Cell lines were cultured in Iscove's modified Dulbecco's medium (IMDM; Gibco Life Technologies, Paisley, Scotland), supplemented with $10 \%$ (v/v) heat-inactivated FCS (ICN Biomedicals $\mathrm{GmbH}$, Meckenhein, Germany), $5 \mathrm{mg} / \mathrm{l}$ gentamycin and $5 \mathrm{mM}$ L-glutamine (Gibco). The Burkitt lymphoma Ramos FSA clone with enhanced response to CD95, the caspase-9-DN (C9DN) overexpressing Ramos FSA cell line, Ramos $2 \mathrm{G} 6$ clone and the Bcl-2 overexpressing Ramos $2 \mathrm{G} 6$ cell line have been described previously. ${ }^{23,39}$ The B-CLL cell line Mec- $1^{40}$ was a kind gift of Dr. Caligaris-Cappio (Milano, Italy). Mock and two Noxa siRNA sequences (N7 or N8) were retrovirally transduced into the Ramos FSA, Mec-1 and J16 cell lines as described previously. ${ }^{20}$ Furthermore, siRNA targeting Bim (pSuper-Bim) was kindly provided by Andreas Villunger (Biocenter, Innsbrück, Austria) and subcloned in the EcoRl/Xho sites of pRetroSuper. After retroviral transduction of $\mathrm{J} 16$ cell line, the B18 and B22 subclones were obtained after limiting dilution. The pcDNA3.1 vector encoding Myc-hMcl-1 was obtained from Professor J Borst (Netherlands Cancer Institute). After digestion with $\mathrm{BamH} 1$ and $\mathrm{Xba}$ the product was inserted into the BamH1 and SnaB1 blunt-ended sites of the LZRS-IRES-GFP vector, resulting in LZRS-Myc-hMcl-1-IRES-GFP.

Reagents. Seliciclib was obtained from Cyclacel Ltd. (Dundee, UK). Fludarabine, staurosporine, etoposide, carbonyl cyanide $m$-chlorophenylhydrazone (CCCP), taxol and propidium iodide $(\mathrm{PI})$ were purchased from Sigma Chemical Co. Anti-human Fas10 (agonistic antibody to the CD95 receptor) and anti-human IgM mAbs (CLB/ $\mathrm{MH} 15$ ) were kind gifts from Professor Dr. L Aarden (Sanquin, Amsterdam, The Netherlands). The pan-caspase inhibitor zVAD-fmk was obtained from Alexis Biochemicals (Läuferlingen, Switzerland). APC-labeled Annexin V was from IQ Products (Groningen, The Netherlands) and MitoTracker Orange was from Molecular Probes (Leiden, The Netherlands). Proteasome inhibitors MG132 and bortezomib, were obtained from Calbiochem, (Amsterdam, The Netherlands) and Janssen-Cilag (Tilburg, The Netherlands), respectively.

Analysis of apoptosis. For cell stimulations, B-CLL cells ( $>90 \%$ $\mathrm{CD} 1{ }^{+} \mathrm{CD}^{+}$PBMC suspensions) were used at a concentration of $1.7 \times 10^{6} \mathrm{cells} / \mathrm{ml}$ in 24-well plate, Ramos and Mec-1 cell lines at a concentration of $5 \times 10^{5} \mathrm{cells} / \mathrm{ml}$. Cells were harvested and washed in ice-cold HEPES buffer (10 mM HEPES, $150 \mathrm{mM} \mathrm{KCl,} 1 \mathrm{mM} \mathrm{MgCl}$ and $1.3 \mathrm{mM} \mathrm{CaCl}_{2}, \mathrm{pH} 7.4$ ), and incubated with APC-labeled Annexin-V (BD Biosciences) for $20 \mathrm{~min}$. Before analyses, PI was added (final concentration $5 \mu \mathrm{g} / \mathrm{ml}$ ). Viable cells were defined by Annexin $\mathrm{V}^{-} / \mathrm{PI}^{-}$staining. Alternatively, cells were incubated with $200 \mathrm{mM}$ MitoTracker for $30 \mathrm{~min}$ at $37^{\circ} \mathrm{C}$. To assess activation of Bax and Bak, B-CLL cells $\left(1 \times 10^{6}\right)$ were washed in PBS prior to fixation in $4 \%$ formaldehyde for $5 \mathrm{~min}$ at room temperature. Cells were washed in PBS and incubated in the presence of $1 \mu \mathrm{g} / \mathrm{ml}$ of anti-Bax (Ab-6, clone $6 \mathrm{~A} 7$; Calbiochem) or anti-Bak (Ab-1; Calbiochem), diluted in permeabilization buffer $(0.5 \% \mathrm{BSA}+500 \mu \mathrm{g} / \mathrm{ml}$ digitonin in PBS) for $30 \mathrm{~min}$ at room temperature. Cells were washed in PBA (PBS $+0.2 \%$ $\mathrm{BSA}+0.02 \% \quad \mathrm{NaN}_{3}$ ) and incubated with goat anti-mouse PE-conjugated secondary antibody (Jackson ImmunoResearch Europe Ltd., Suffolk, England), diluted $1 / 200$ in permeabilization buffer for $30 \mathrm{~min}$ at room temperature. Cells were washed with PBA, re-suspended in PBS and analyzed using the FACS.

Western blotting and IP. Cell lysates for western blotting were separated by $13 \%$ sodium dodecyl sulfate-polyacrylamide gel electrophoresis (SDS-PAGE) followed by western blotting as described previously. ${ }^{23}$ Blots were probed with the following antisera: monoclonal anti-Mcl-1 (BD Pharmingen), monoclonal anti-Bax (BD Pharmingen), Bak monoclonal antibody (mAb) (Upstate Biotechnology, Inc. Lake Placid, NY, USA), monoclonal anti-Bim (Figures 2 and 5a; Chemicon, Temecula, CA, USA), polyclonal anti-Bim (Figures 3Ac and 5b; Nventa, San Diego, CA, USA) monoclonal anti-Noxa from Imgenex (San Diego, CA, USA), polyclonal anti-Bcl-2 (Alexis Biochemicals), polyclonal cleaved caspase-3 (Asp175) antibody, polyclonal anti-p44/42-MAP Kinase (Cell signaling Technology Inc., Danvers, MA, USA) antibody and antiserum to $\beta$-actin was from Santa Cruz Biotechnology, Inc. (Santa Cruz, CA, USA).

For IP of Mcl-1, $50 \times 10^{6}$ cells were washed two times in ice-cold PBS (supplemented with $10 \mathrm{mM} \mathrm{Na}_{3} \mathrm{VO}_{4}$ ) and lysed in $500 \mu$ lice-cold Triton X-100 lysis buffer (1\% Triton X-100, $20 \mathrm{mM}$ Tris-Cl (pH=7.4), $135 \mathrm{mM} \mathrm{NaCl}, 1.5 \mathrm{mM} \mathrm{MgCl}_{2}$, $10 \%$ Glycerol, $2 \mu \mathrm{g} / \mathrm{ml}$ leupeptin, $1 \mathrm{mM}$ PMSF and $2 \mu \mathrm{g} / \mathrm{ml}$ Trypsin inhibitor). Whole cell lysates were precleared with normal rabbit serum precoupled to protein Asepharose and incubated for $3 \mathrm{~h}$ with $5 \mu \mathrm{g}$ polyclonal anti-Mcl-1 (BD Pharmingen) precoupled to protein A-sepharose. Beads were pelleted, washed six times with lysis buffer and boiled in SDS sample buffer, and further processed for western blotting.

CHAPS lysates were used in certain experiments to avoid detergent-induced conformational changes of Bax, ${ }^{30}$ by lysing $50 \times 10^{6}$ cells (for IP) or $15 \times 10^{6}$ cells (for western blot) for $30 \mathrm{~min}$ on ice in lysis buffer (1\% 3[(3-cholamidopropyl)dimethylammonio]-propane-sulfonic acid (CHAPS), $20 \mathrm{mM}$ Tris- $\mathrm{Cl}(\mathrm{pH}=7.4)$, $135 \mathrm{mM} \mathrm{NaCl}, 1.5 \mathrm{mM} \mathrm{MgCl}_{2}, 10 \%$ glycerol, $1 \mathrm{mM}$ EGTA, $2 \mathrm{mM} \mathrm{Na}_{3} \mathrm{VO}_{4}, 10 \mathrm{mM}$ $\mathrm{NaF}, 2 \mu \mathrm{g} / \mathrm{ml}$ leupeptin, $1 \mathrm{mM}$ PMSF, $0.1 \mathrm{mM}$ TLCK and $2 \mu \mathrm{g} / \mathrm{ml}$ Trypsin inhibitor). After centrifugation $\left(15 \mathrm{~min} ; 13000 \times \mathrm{g} ; 4^{\circ} \mathrm{C}\right.$ ), the supernatant was used for IP or as 'CHAPS soluble fraction' on western blot. Pellets were solubilized in SDS sample buffer and used in western blotting as the 'CHAPS insoluble fraction'. IP of Bim (monoclonal anti-Bim (Chemicon)) was performed as described above in $500 \mu$ licecold CHAPS and lysates were precleared with normal rat serum precoupled to protein G-sepharose.

Immunocytochemistry and confocal analysis. B-CLL cells were incubated with $200 \mathrm{nM}$ MitoTracker for $24 \mathrm{~h}$ at $37^{\circ} \mathrm{C}$ and treated as described above (intracellular flow cytometry procedure). Cells $\left(1 \times 10^{6}\right)$ were re-suspended in $25 \mu$ l vectashield (Hardset with DAPI; Vector Laboratories, CA, USA) and were spotted on coverslips. Images were independently captured by confocal laser microscopy (model TCS 4D, Leica, Heidelberg, Germany) at the wavelengths 488 
and $594 \mathrm{~nm}$ lines of the krypton/argon laser used for the excitation of FITC and MitoTracker (Alexa594), respectively. Excitation of DAPI was by $594 \mathrm{~nm}$.

Statistical analyses. The Student's t-test was used for analysis of differences between two groups. $P<0.01$ were considered statistically significant.

Acknowledgements. We thank Bart de Goeij for his technical assistance. We also thank the patients for their blood donations. We also acknowledge Dr. Kramer, Dr. Wittebol and Dr. Baars for including B-CLL patients in this study. This work was supported by the Dutch Cancer Foundation (DCF) Grant no. UVA2004-3039

1. Byrd JC, Stilgenbauer S, Flinn IW. Chronic lymphocytic leukemia. Hematology (Am Soc Hematol Educ Program) 2004: 163-183.

2. Robertson LE, Plunkett W, McConnell K, Keating MJ, McDonnell TJ. Bcl-2 expression in chronic lymphocytic leukemia and its correlation with the induction of apoptosis and clinical outcome. Leukemia 1996; 10: 456-459.

3. Kitada S, Andersen J, Akar S, Zapata JM, Takayama S, Krajewski S et al. Expression of apoptosis-regulating proteins in chronic lymphocytic leukemia: correlations with in vitro and in vivo chemoresponses. Blood 1998; 91: 3379-3389.

4. Weinstein IB, Joe AK. Mechanisms of disease: oncogene addiction - a rationale fo molecular targeting in cancer therapy. Nat Clin Pract Oncol 2006; 3: 448-457.

5. Strasser A. The role of BH3-only proteins in the immune system. Nat Rev Immunol 2005; 5 189-200.

6. Mackus WJ, Kater AP, Grummels A, Evers LM, Hooijbrink B, Kramer MH et al. Chronic lymphocytic leukemia cells display p53-dependent drug-induced Puma upregulation. Leukemia 2005; 19: 427-434.

7. Nakano K, Vousden KH. PUMA, a novel proapoptotic gene, is induced by p53. Mol Cell 2001; 7: 683-694.

8. Yu J, Zhang L, Hwang PM, Kinzler KW, Vogelstein B. PUMA induces the rapid apoptosis of colorectal cancer cells. Mol Cell 2001; 7: 673-682.

9. Hahntow IN, Schneller F, Oelsner M, Weick K, Ringshausen I, Fend F et al. Cyclindependent kinase inhibitor Roscovitine induces apoptosis in chronic lymphocytic leukemia cells. Leukemia 2004; 18: 747-755.

10. Byrd JC, Lin TS, Dalton JT, Wu D, Phelps MA, Fischer B et al. Flavopiridol administered using a pharmacologically derived schedule is associated with marked clinical efficacy in refractory, genetically high-risk chronic lymphocytic leukemia. Blood 2007; 109: 399-404.

11. MacCallum DE, Melville J, Frame S, Watt K, Anderson S, Gianella-Borradori A et Seliciclib (CYC202, R-Roscovitine) induces cell death in multiple myeloma cells by inhibition of RNA polymerase II-dependent transcription and down-regulation of $\mathrm{Mcl}-1$. Cancer Res 2005; 65: 5399-5407.

12. Wei MC, Zong WX, Cheng EH, Lindsten T, Panoutsakopoulou V, Ross AJ et al. Proapoptotic BAX and BAK: a requisite gateway to mitochondrial dysfunction and death. Science 2001; 292: 727-730.

13. Chen L, Willis SN, Wei A, Smith BJ, Fletcher JI, Hinds MG et al. Differential targeting of

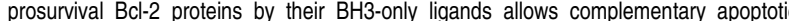
function. Mol Cell 2005; 17: 393-403.

14. Kuwana T, Bouchier-Hayes L, Chipuk JE, Bonzon C, Sullivan BA, Green DR et al. BH3 domains of $\mathrm{BH} 3$-only proteins differentially regulate Bax-mediated mitochondrial membrane permeabilization both directly and indirectly. Mol Cell 2005; 17: 525-535.

15. Collins RJ, Verschuer LA, Harmon BV, Prentice RL, Pope JH, Kerr JF. Spontaneous programmed death (apoptosis) of B-chronic lymphocytic leukaemia cells following their culture in vitro. Br J Haematol 1989; 71: 343-350.

16. Herrant M, Jacquel A, Marchetti S, Belhacene N, Colosetti P, Luciano F et al. Cleavage of $\mathrm{Mcl}-1$ by caspases impaired its ability to counteract Bim-induced apoptosis. Oncogene 2004; 23: 7863-7873.

17. Certo M, Del Gaizo Moore V, Nishino M, Wei G, Korsmeyer S, Armstrong SA et al. Mitochondria primed by death signals determine cellular addiction to antiapoptotic BCL-2 family members. Cancer Cell 2006; 9: 351-365.

18. Gomez-Bougie $\mathrm{P}$, Bataille R, Amiot $\mathrm{M}$. Endogenous association of Bim BH3-only protein with Mcl-1, Bcl-xL and Bcl-2 on mitochondria in human B cells. Eur J Immunol 2005; 35 971-976.
19. Willis SN, Chen L, Dewson G, Wei A, Naik E, Fletcher Jl et al. Proapoptotic Bak is sequestered by $\mathrm{Mcl}-1$ and $\mathrm{Bcl}-\mathrm{xL}$, but not Bcl-2, until displaced by BH3-only proteins. Genes Dev 2005; 19: 1294-1305.

20. Alves NL, Derks IA, Berk E, Spijker R, van Lier RA, Eldering E. The Noxa/Mcl-1 axis regulates susceptibility to apoptosis under glucose limitation in dividing $T$ cells. Immunity 2006; 24: 703-716.

21. Sunters A, Fernandez de MS, Stahl M, Brosens JJ, Zoumpoulidou G, Saunders CA et al. FoxO3a transcriptional regulation of Bim controls apoptosis in paclitaxel-treated breast cancer cell lines. J Biol Chem 2003; 278: 49795-49805.

22. Dewson G, Snowden RT, Almond JB, Dyer MJ, Cohen GM. Conformational change and mitochondrial translocation of Bax accompany proteasome inhibitor-induced apoptosis of chronic lymphocytic leukemic cells. Oncogene 2003; 22: 2643-2654.

23. van der Kolk LE, Evers LM, Omene C, Lens SM, Lederman S, van Lier RA et al. CD20induced B cell death can bypass mitochondria and caspase activation. Leukemia 2002; 16 : 1735-1744.

24. Kobayashi S, Lee SH, Meng XW, Mott JL, Bronk SF, Werneburg NW et al. Serine 64 phosphorylation enhances the antiapoptotic function of Mcl-1. J Biol Chem 2007; 282 : 18407-18417

25. Lin K, Sherrington PD, Dennis M, Matrai Z, Cawley JC, Pettitt AR. Relationship between p53 dysfunction, CD38 expression, and $\operatorname{lgV}(\mathrm{H})$ mutation in chronic lymphocytic leukemia. Blood 2002; 100: 1404-1409.

26. Oltersdorf T, Elmore SW, Shoemaker AR, Armstrong RC, Augeri DJ, Belli BA et al. An inhibitor of Bcl-2 family proteins induces regression of solid tumours. Nature 2005; 435 : 677-681.

27. Kim H, Rafiuddin-Shah M, Tu HC, Jeffers JR, Zambetti GP, Hsieh JJ et al. Hierarchical regulation of mitochondrion-dependent apoptosis by BCL-2 subfamilies. Nat Cell Biol 2006; 8: $1348-1358$.

28. Harada H, Quearry B, Ruiz-Vela A, Korsmeyer SJ. Survival factor-induced extracellular signal-regulated kinase phosphorylates BIM, inhibiting its association with BAX and proapoptotic activity. Proc Natl Acad Sci USA 2004; 101: 15313-15317.

29. Cartron PF, Gallenne T, Bougras G, Gautier F, Manero F, Vusio P et al. The first alpha helix of Bax plays a necessary role in its ligand-induced activation by the $\mathrm{BH} 3$-only proteins $\mathrm{Bid}$ and PUMA. Mol Cell 2004; 16: 807-818.

30. Willis SN, Fletcher Jl, Kaufmann T, van Delft MF, Chen L, Czabotar PE et al. Apoptosis initiated when $\mathrm{BH} 3$ ligands engage multiple Bcl-2 homologs, not Bax or Bak. Science 2007; 315: $856-859$.

31. Uren RT, Dewson G, Chen L, Coyne SC, Huang DC, Adams JM et al. Mitochondrial permeabilization relies on $\mathrm{BH} 3$ ligands engaging multiple prosurvival $\mathrm{Bcl}-2$ relatives, not Bak. J Cell Biol 2007; 177: 277-287.

32. Wolter KG, Hsu YT, Smith CL, Nechushtan A, Xi XG, Youle RJ. Movement of Bax from the cytosol to mitochondria during apoptosis. J Cell Biol 1997; 139: 1281-1292.

33. Antonsson B, Conti F, Ciavatta A, Montessuit S, Lewis S, Martinou I et al. Inhibition of Bax channel-forming activity by Bcl-2. Science 1997; 277: 370-372.

34. Han J, Goldstein LA, Hou W, Rabinowich H. Functional linkage between Noxa and Bim in mitochondrial apoptotic events. J Biol Chem 2007; 282: 16223-16231.

35. Konopleva M, Contractor R, Tsao T, Samudio I, Ruvolo PP, Kitada S et al. Mechanisms of apoptosis sensitivity and resistance to the $\mathrm{BH} 3$ mimetic ABT-737 in acute myeloid leukemia. Cancer Cell 2006; 10: 375-388.

36. van Delft MF, Wei AH, Mason KD, Vandenberg CJ, Chen L, Czabotar PE et al. The BH3 mimetic ABT-737 targets selective Bcl-2 proteins and efficiently induces apoptosis via Bak/ Bax if Mcl-1 is neutralized. Cancer Cell 2006; 10: 389-399.

37. Smit LA, Hallaert DY, Spijker R, de GB, Jaspers A, Kater AP et al. Differential Noxa/Mcl-1 balance in peripheral versus lymph node chronic lymphocytic leukemia cells correlates with survival capacity. Blood 2006; 1: 1.

38. Chen S, Dai $Y$, Harada H, Dent P, Grant S. Mcl-1 down-regulation potentiates ABT-737 lethality by cooperatively inducing Bak activation and Bax translocation. Cancer Res 2007; 67: 782-791.

39. Eldering E, Mackus WJ, Derks IA, Evers LM, Beuling E, Teeling P et al. Apoptosis via the $B$ cell antigen receptor requires Bax translocation and involves mitochondrial depolarization, cytochrome $c$ release, and caspase-9 activation. Eur J Immunol 2004; 34: 1950-1960.

40. Stacchini A, Aragno M, Vallario A, Alfarano A, Circosta P, Gottardi D et al. MEC1 and MEC2: two new cell lines derived from B-chronic lymphocytic leukaemia in prolymphocytoid transformation. Leuk Res 1999; 23: 127-136. 